\title{
KUALITAS BIOLOGIS AIR KOLAM RENANG UMUM DI KOTA TANGERANG
}

\author{
Aminah, Makhabbah Jamilatun \\ Poltekkes Kemenkes Banten \\ Email: aminah.vet@gmail.com
}

\begin{abstract}
Various studies have shown that swimming pool mismanagement could serve as medium for water-borne diseases transmission. The research aimed to assess the biological quality of public swimming pool water in Tangerang city. One public swimming pool at the center of Tangerang city was assessed during November - December 2016 by adding two parameters to routine bacteriological indicators assessed by Tangerang city Heath Official in public facilities. Nine samples taken from three points in the swimming pool at three time periods, i.e. before, after, and during operational hours were analysed in the laboratory for detection and quantificaton of bacteriological indicators of swimming pool water, i.e. coliform, Escherichia coli, Staphylococcus, and Pseudomonas aeruginosa. Results showed that the number of total coliform and Escherichia coliof the public swimming pool exceeded WHO guidelines but not Peudomonas and Staphylococcus. Therefore, the disinfection, cleaning, and monitoring procedures need to be improved as well as increasing public swimming pool users education about the risk of potential transmissible diseases in public swimming pool.
\end{abstract}

Keywords: bacteriological indicators, hygiene, swimming pool, water quality

\section{ABSTRAK}

Berbagai kajian menunjukkan bahwa pengelolaan kolam renang yang tidak tepat dapat menjadi sarana penularan penyakit bersumber air. Penelitian ini bertujuan untuk memeriksa kualitas biologis air kolam renang umum di Kota Tangerang.

Satu kolam renang umum yang terletak di pusat kota Tangerang diperiksa pada bulan November - Desember 2016 dengan penambahan dua parameter pemeriksaan selain parameter pemeriksaan indikator bakteriologis rutin terhadap fasilitas umum yang dilakukan oleh Dinas Kesehatan Kota Tangerang.Sebanyak sembilan sampel air yang berasal dari tiga titik di kolam renang dari tiga waktu pengambilan yaitu sebelum, sesudah, dan pertengahan waktu penggunaan kolam renang umumdianalisis di laboratorium untuk mendeteksi dan menghitung jumlah bakteri indikator pencemaran air kolam renang seperti koliform, Escherichia coli, Staphylococcus, dan Pseudomonas aeruginosa.

Hasil pemeriksaan menunjukkan bahwa jumlah bakteri indikator koliform total dan Escherichia coli di kolam renang umum melebihi batas panduan WHO namun tidak demikian halnya dengan Pseudomonas dan Staphylococcus.Oleh karena itu prosedur disinfeksi, kebersihan, dan pengawasan kualitas air perlu diperbaiki selain peningkatan edukasi pengguna kolam renang umum mengenai potensi risiko penyakit menular di kolam renang umum.

Kata kunci: indikator bakteriologis, kebersihan, kolam renang, kualitas air. 


\section{PENDAHULUAN}

Secara rutin lembaga pemerintah seperti Dinas Kesehatan Kota telah melakukan pemeriksaan berkala untuk memantau aspek kesehatan dan keamanan pengelolaan setiap fasilitas umum seperti kolam renang. Namun parameter yang digunakan masih terbatas. Sebagai contoh, dari aspek biologis hanya dilakukan pemeriksaan untuk mendeteksi keberadaan koliform fekal yang merupakan indikator pencemaran sumber air secara umum. Selain itu, data yang diperoleh hanya digunakan untuk kalangan terbatas sehingga tidak ada referensi yang dapat dijadikan rujukan oleh publik. Melalui penelitian ini kami telah menambahkan parameter pemeriksaan mikrobiologis air kolam renang dan hasilnya nanti diharapkan dapat menjadi rujukan bagi publik maupun peneliti lain.

Selain koliform fekal, bakteri nonfekal juga dapat ditemukan di kolam renang, antara lain Pseudomonas, Staphylococcus aureus, Legionella, Mycobacterium dan Leptospira. Bakteri bersumber feses seperti Shigella dan E.coli 0157 dapat masuk kedalam air kolam renang selama proses pembersihan atau berasal dari tubuh pengguna kolam renang ketika seseorang mengalami pengeluaran feses secara tidak sengaja. Kontaminasi air oleh mikroorganisme yang berasal dari kulit, rambut, saliva, urin, feses, ataupun darah dari pengguna kolam renang ini berpotensi menyebabkan infeksi melalui tiga rute penularan yaitu termakan/terminum, terhirup, dan kontak dengan kulit/mukosa. Dari semua itu, pencemaran air oleh feses merupakan risiko mikrobiologis utama bagi pengguna kolam renang dan rekreasi air lainnya ${ }^{1}$.Staphylococci merupakan bakteri umum pada kulit yang dapat ditemukan di arena rekreasi air (Valeriani F, Giampaoli S, 2012)dan digunakan sebagai indikator risiko penyakit kulit, mata, dan telinga (Valeriani F, Giampaoli S, 2012). (Carmo MRdC, Chavasco JK, 2014) Pseudomonads dan terutama Pseudomonas aeruginosa dapat hidup pada kondisi lembab, hangat dan rendah bahan organik sehingga dapat ditemukan di berbagai tempat di kolam renang (Valeriani F, Giampaoli S, Romano Spica V. 2014). Selain itu, Legionella pneumophila juga dapat ditemukan di aliran air yang bersirkulasi di kolam renang yang pemeliharaannya tidak tepat (Napoli C, Fasano F,. 2010). Escherichia coli dapat ditemukan di setiap tempat di kolam renang dengan kuaitas air rendah serta dapat berpindah dari tubuh pengguna kolam renang kedalam air atau dari pengeluaran feses secara tidak sengaja.( Marion JW, Lee J, Lemeshow S, Buckley 
TJ. 2010.) dan (Zhan X-Y, Hu C-H, Zhu Q-Y. 2014)

Berdasarkan temuan-temuan di atas, parameter mikrobiologis yang dapat digunakan untuk menilai kulitas biologis air kolam renang antara lain koliform

\section{METODE}

Pengambilan dan pemeriksaan sampel dilaksanakan pada bulan Desember 2016. Sampel diambil dari air kolam renang umum di Kota Tangerang. Sampel diambil secara purposive sampling. Data primerdiperoleh setelah pengujian dilakukan terhadap 9 spesimen yang berasal dari satu kolam renang umum di kota Tangerang.

Sebanyak 9sampel yang berasal dari kolam renang umum di kota Tangerang diambil di tiga titik di kolam renang olah raga (dangkal, tengah, dalam); pada waktu sebelum disinfeksi dan pembersihan kolam renang(setelah jam operasional), sebelum penggunaan (sebelum jam operasional), dan pertengahan waktu operasional. Sampel dikumpulkan menggunakan botol steril leher sempit dan tongkat sampling kemudian langsung dibawa ke

\section{HASIL DAN PEMBAHASAN}

Pemeriksaan bakteriologis dilakukan terhadap enam sampel yang diambil sebelum, pertengahan, dan setelah jam fekal, Staphylococcus aureus, Pseudomonas aeruginosa, Legionella, Escherichia coli (Eaton AD, American Public Health A, American Water Works A, 2005 ).

laboratorium dalam kontainer dalam kondisi dingin $\left(4-10^{\circ} \mathrm{C}\right)$ untuk segera diinokulasikan pada media uji.

Isolasi dan Identifikasi Bakteri Pencemar Air Kolam Renang

Untuk penghitungan koliform per100ml sampel, inkubasidilakukan pada suhu $37^{\circ} \mathrm{C}$ dan $44{ }^{\circ} \mathrm{C}$ menggunakan teknik MPN. Staphylococcus aureus per $100 \mathrm{ml}$ pada $36^{\circ} \mathrm{C}, \quad$ media MSA.Pseudomonas aeruginosa per $100 \mathrm{ml}$ pada $30^{\circ} \mathrm{C}$ menggunakan media Pseudomonas Selective Agar Base Cetrimide. Konfirmasi dan penegasan Escherichia coli pada media EMBA $37^{\circ} \mathrm{C}$.

Data hasil pemeriksaan laboratorium terhadap sampel disajikan secara deskriptif dalam bentuk tabel dengan

panduan penilaian kulaitas air kolam renang dari WHO sebagai pembanding.

operasional berkhir. Dari pemeriksaan air di laboratorium ditemukan bahwa kontaminasi air

kolam yang terjadi selama masa 
operasional kolam tidak dapat dieliminasi sebagaimana disajikan pada Tabel 1.

oleh filter dalam sistem sirkulasi dan hanya dapat diatasi dengan penambahan klorin

Tabel 1. Hasil pemeriksaan bakteriologis air kolam sesudah penggunaan

\begin{tabular}{lcccc}
\hline \multicolumn{1}{c}{ Parameter } & Panduan & \multicolumn{3}{c}{ Kolam Renang Umum } \\
\cline { 3 - 5 } & WHO & Sebelum* & Pertengahan* & Setelah* \\
\hline Coliform & $<1$ & - & $116,3 \pm 113,8$ & $104,4 \pm 120,6$ \\
Thermotolerant & $<1$ & - & $6,7 \pm 2,9$ & $29,7 \pm 29,9$ \\
coliform & & - & + & +++ \\
Escherichia oli & $<1$ & $0,3 \pm 0,6$ & $0,7 \pm 1,2$ & $1 \pm 1$ \\
Staphylococcus & $<200$ & - & - & - \\
Pseudomonas & $<1$ & & & + \\
\hline
\end{tabular}

* Jam operasional $(07.00-19.00)$

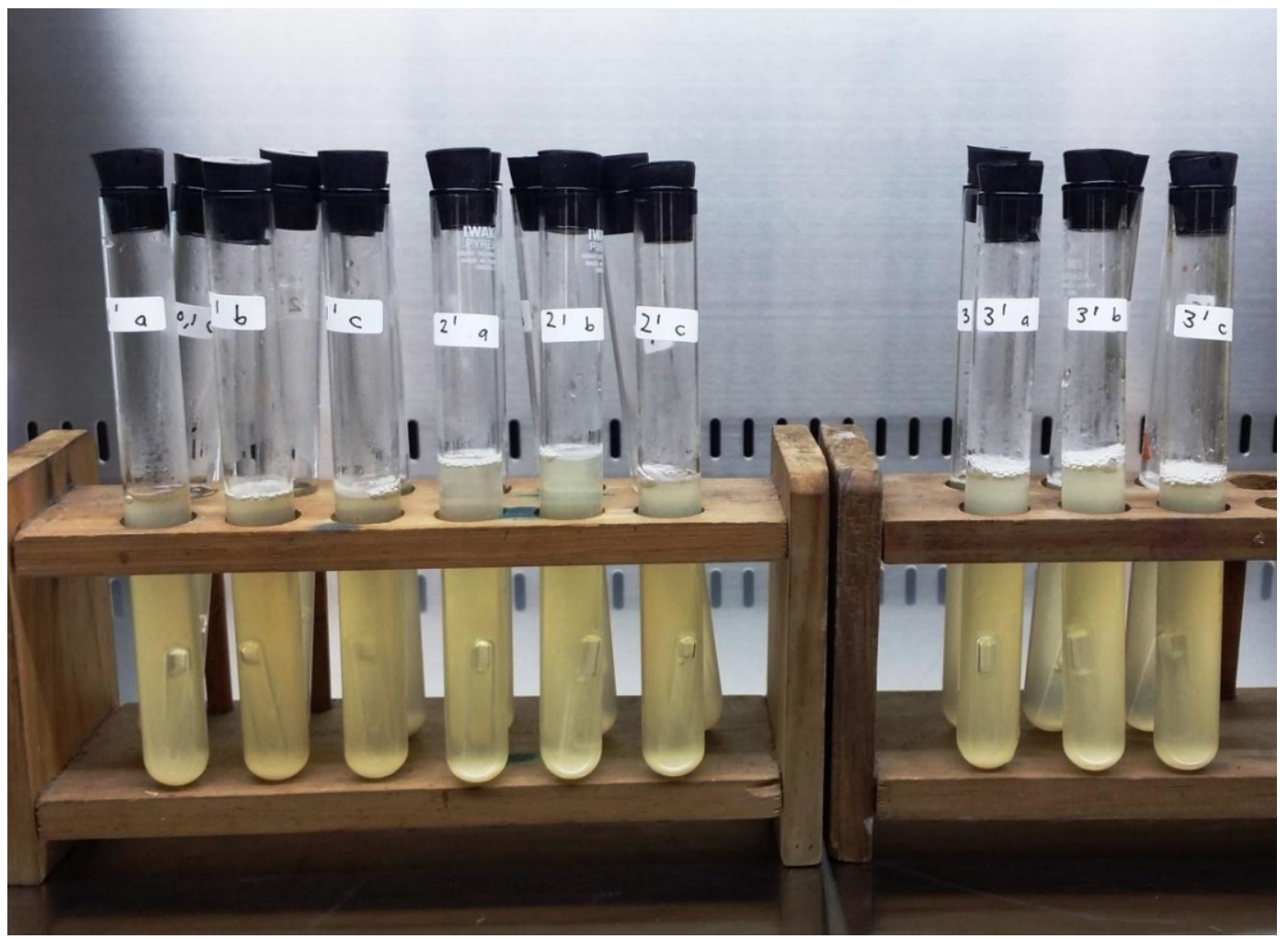

Gambar 1. Inokulasi pada media LB untuk melihat pembentukan gas yang menandakan pertumbuhan bakteri yang mampu memfermentasi laktosa. 


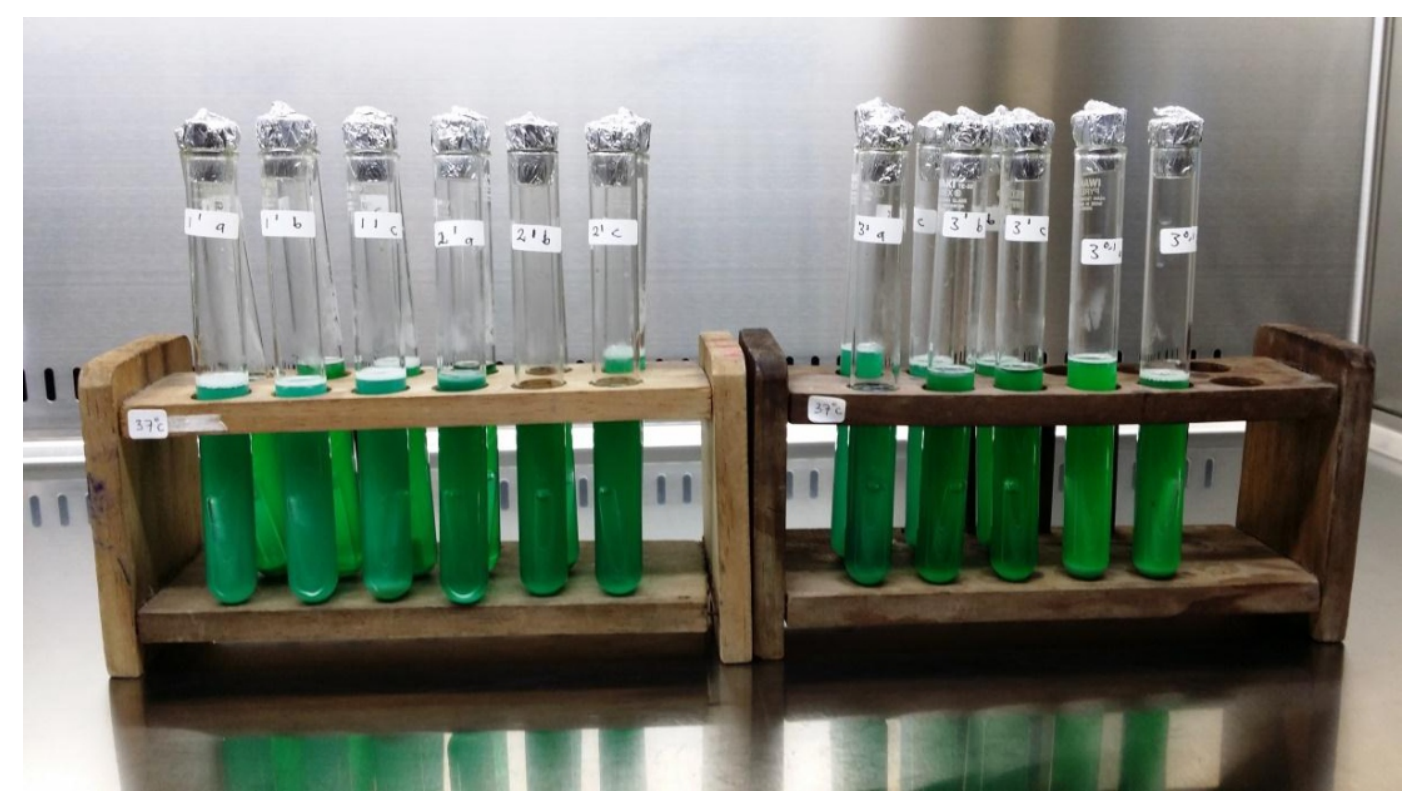

Gambar 2. Media BGLB untuk melihat pembentukan gas yang menandakan pertumbuhan bakteri Coliform.

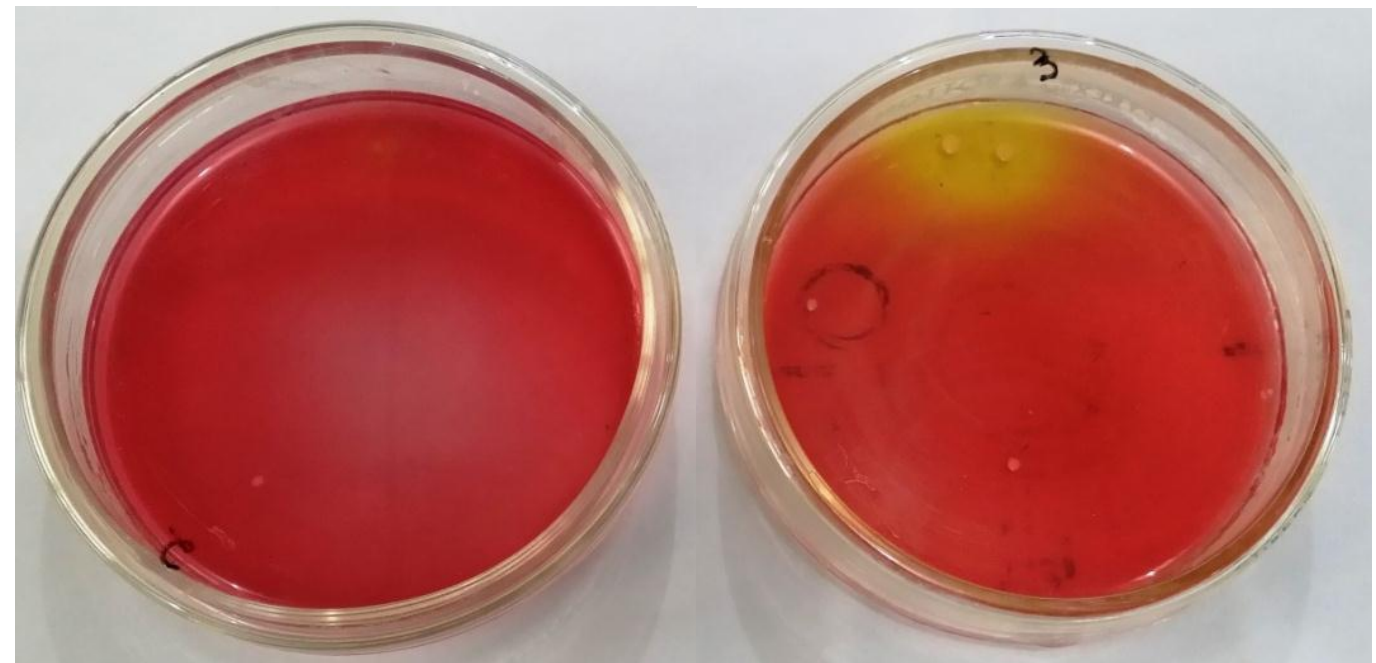

Gambar 3. Pertumbuhan Staphylococcus mengubah media MSA menjadi kuning

Secara umum kolam renang yang diteliti dapat dibagi menjadi dua kategori, yaitu kolam olah raga dengan bentuk persegi panjang olympic size, dan kolam rekreasi yang terdiri dari kolam air mancur dan kolam arus. Kolam olah raga lebih banyak digunakan oleh orang dewasa dan anak sekolah yang datang untuk tujuan berolah raga. Sedangkan kolam rekreasi didominasi oleh anak-anak yang datang bersama orang tua mereka untuk berekreasi.

Kolam renang beroperasi 12 jam sehari mulai dari jam 07.00 pagi hingga 
19.00 malam. Disinfeksi air dilakukan dengan penaburan klorin ke dalam kolam setiap hari setelah jam operasional kolam. Dengan sirkulasi, klorin menyebar ke seluruh air kolam sedangkan kotoran yang menyebabkan air menjadi keruh diendapkan semalam kemudian disedot pada pagi hari sebelum jam operasional.

Sistem sirkulasi membuat air dari kolam melewati satu filter. Semua air yang berasal dari setiap kolam akan masuk ke bak balancing kemudian menuju filter dan didistribusikan kembali ke kolam sehingga kondisi air akan sama di setiap kolam. Sistem ini dapat dikatakan efisien karena semua kolam mendapatkan perlakuan yang sama namun juga merugikan karena kontaminasi di salah satu kolam dapat menyebar ke semua kolam lainnya.

Bakteri indikator cemaran dapat ditemukan di tengah dan setelah jam operasional kolam.Angka cemaran paling mendekati di tengah jam operasional untuk koliform adalah $116,3 \pm 113,8$, koliform termotoleran 6,7 $\pm 2,9$, dan Staphylococcus $0,7 \pm 1,2$. Bakteri fekal dapat masuk kedalam air kolam renang selama proses pembersihan, dari kulit atau saliva maupun mukus pengguna kolam renang atau dari pengeluaran feses secara tidak sengaja. Setelah jam operasional jumlah koliform termotoleran menjadi lebih tinggi yaitu $29,7 \pm 29,9$, dan Staphulococcus $1 \pm 0,8$, sedangkan koliform 104,4 $\pm 120,6$.Escherichia coli juga dapat dideteksi pada kedua waktu ini. Hal ini menunjukkan bahwa sistem filtrasi dan disinfeksi yang diterapkan tidak efektif menjaga kualitas air kolam renang selama masa penggunaan. Bakteri non-fekal yang diperiksa adalah Pseudomonas dan Staphylococcus dan dari hasil kultur di laboratorium tidak ditemukan Pseudomonas namun didapatkan $1 \mathrm{cfu}$ Staphylococcus di kolam bagian tengah, 2 cfu di bagian kolam yang dalam setelah jam operasional kolam.

Kualitas bakteriologis kolam renang ini memenuhi sekaligus tidak memenuhi standar kesehatan. Angka kuman terdekat untuk koliform dan E. coli melebihi standar namun angka total Staphylococcus dan Pseudomonas masih dapat diterima (Guida M, Galle F, Mattei ML, Anastasi D, Liguori G. 2009), (Amagliani G, Schiavano GF, Stocchi V, Bucci G, Brandi G. 2013). Dalam kajian lain, spesies bakteri yang paling banyak ditemukan di kolam renang antara lain Pseudomonas aeruginosa, $\quad$ E. coli, dan Enterokokus((Casanovas-Massana A, Blanch AR. 2013.). Kontaminasi air kolam renang oleh mikroba antara lain disebabkan oleh klorinasi yang tidak teratur, filtrasi yang tidak efektif, jumlah pengunjung yang tinggi, rendahnya 
pengetahuan pengunjung, dan masuk ke kolam renang tanpa mandi terlebih dahulu. Setiap hari kolam renang umum yang diperiksa selalu menerima pengunjung dalam jumlah besar sehingga potensi kontaminasi fekal maupun patogen lain menjadi tinggi (Casanovas-Massana A, Blanch AR. 2013.) karena kondisi sanitasi pengunjung sulit untuk dikendalikan. Akibatnya, sistem filtrasi dan disinfeksi satu kali sehari menjadi tidak cukup untuk mengurangi mikroorganisme dan kontaminasi fekal. Oleh karena itu prosedur disinfeksi, kebersihan, dan pengawasan kualitas air perlu diperbaiki selain peningkatan edukasi pengguna kolam renang umum mengenai potensi risiko penyakit menular di kolam renang

\section{SIMPULAN}

Bakteri indikator cemaran dapat ditemukan di kolam renang umum Kota Tangerang di tengah dan setelah jam operasional kolam. Angka cemaran paling mendekati di tengah jam operasional untuk koliform adalah $116,3 \pm 113,8$, koliform termotoleran

\section{DAFTAR RUJUKAN}

WHO. 2006. Guidelines for safe recreational water environments. In swimming pools and similar environments, World Health Organization, Geneva

Valeriani F, Giampaoli S, Buggiotti L, Gianfranceschi G, Romano Spica V. 2012. Molecular enrichment for umum.

Beberapa penelitian menunjukkan bahwa jumlah residu klorin bebas $1 \mathrm{mg} / 1$ dapat mengurangi Escherichia coli, Legionella pneumophila, Pseudomonas aeruginosa, Staphylococcus aureus, dan Candida albicans ${ }^{18,}$ (Borgmann-Strahsen R. 2003.) selain faktor turbiditas, oksigen terlarut, dan alkalinitas yang juga menentukan kualitas mikrobiologis air( Ibarluzea J, Moreno B, Zigorraga C, 1998).Beberapa prosedur yang dapat diterapkan untuk mempertahankan residu klorin bebas dalam air antara lain klorinasi pasif atau penggunaan Aquatab yang keduanya melepaskan klorin ke air dalam jumlah yang dapat ditargetkan (Pickering AJ, Crider Y 2015).

$6,7 \pm 2,9$, dan Staphylococcus $\quad 0,7 \pm 1,2$; setelah jam operasional untuk koliform adalah $104,4 \pm 120,6$, koliform termotoleran 29,7 $\pm 29,9$, dan Staphulococcus $1 \pm 0,8$, dan Escherichia coli dapat ditemukan di kedua waktu tersebut.

detection of S. aureus in recreational waters. Water Sci Technol 66: 2305-10

Carmo MRdC, Chavasco JK, Frnzolin SdOB, Beijo LA, Cruz JRdS, Weckwerh PH. 2014. Microbiological assessment of dentists' hands in clinical performance. African Journal of Microbiology Research 8: 797-802 
Valeriani F, Giampaoli S, Romano Spica V. 2014. The molecular enrichment approach for the identification of microbiological indicators in recreational waters. Microchemical Journal 112: 70-4

Napoli C, Fasano F, Iatta R, Barbuti G, Cuna T, Montagna MT. 2010. Legionella spp. and legionellosis in southeastern Italy: disease epidemiology and environmental surveillance in community and health care facilities. BMC Public Health 10: 1471-2458

Marion JW, Lee J, Lemeshow S, Buckley TJ. 2010. Association of gastrointestinal illness and recreational water exposure at an inland U.S. beach. Water Research 44: 4796-804

Akhter A, Imran M, Akhter F. 2014. Determination of multiple antibiotic resistance patterns and indexing among metal tolerant $\beta$ lactamaseproducing Escherichia coli. African Journal of Microbiology Research 8: 619-27

Zhan X-Y, Hu C-H, Zhu Q-Y. 2014. Comparative study on sampling methods for monitoring Legionella species in environmental water. $A f r$ J Microbiol Res 8: 974-85

Eaton AD, American Public Health A, American Water Works A, Water Environment F. 2005. Standard methods for the examination of water \& wastewater. Washington, D.C.: American Public Health Association

Thomas HL, Murray V. 2008. Review of acute chemical incidents involving exposure to chlorine associated with swimming pools in England and Wales, June-October 2007. J Public Health 30: 391-7

Barna Z, Kadar M. 2012. The risk of contracting infectious diseases in public swimming pools. A review. Ann Ist Super Sanita 48: 374-86

Liguori G, Castaldi S, Signorelli C, Auxilia F, Alfano V, Saccani E, Visciano A, Fanti M, Spinelli A, Pasquarella C. 2007. [Hygienic risks in swimming pool: knowledge and behaviours of consumers of three structures in Crema, Parma and Naples]. Ann Ig 19: 325-35

Le Cann P, Bonvallot N, Glorennec P, Deguen S, Goeury C, Le Bot B. 2011. Indoor environment and children's health: Recent developments in chemical, biological, physical and social aspects. International Journal of Hygiene and Environmental Health 215: $1-18$

Abd El-Salam MM. 2012. Assessment of water quality of some swimming pools: a case study in Alexandria, Egypt. Environ Monit Assess 184: 7395-406

Guida M, Galle F, Mattei ML, Anastasi D, Liguori G. 2009. Microbiological quality of the water of recreational and rehabilitation pools: a 2-year survey in Naples, Italy. Public Health 123: 448-51

Amagliani G, Schiavano GF, Stocchi V, Bucci G, Brandi G. 2013. Application of real-time PCR to Pseudomonas aeruginosa monitoring in a public swimming pool. Microchemical Journal 110: 656-9

Casanovas-Massana A, Blanch AR. 2013. Characterization of microbial 
populations associated with natural swimming pools. Int J Hyg Environ Health 216: 132-7

Chu TS, Cheng SF, Wang GS, Tsai SW. 2013. Occupational exposures of airborne trichloramine at indoor swimming pools in Taipei. Sci Total Environ 461-462: 317-22

Borgmann-Strahsen R. 2003. Comparative assessment of different biocides in swimming pool water. International Biodeterioration \& Biodegradation 51: 291-7

Ibarluzea J, Moreno B, Zigorraga C, Castilla T, Martinez M, Santamaria
J. 1998. Determinants of the microbiological water quality of indoor swimming-pools in relation to disinfection. Water Research 32: 865-71

Pickering AJ, Crider Y, Amin N, Bauza V, Unicomb L, Davis J, Luby SP. 2015. Differences in field effectiveness and adoption between a novel automated chlorination system and household manual chlorination of drinking water in Dhaka, Bangladesh: a randomized controlled trial. PLoS One 10: e0118397 
